\title{
Model Evaluasi Penerapan Good Farming Practice pada Peternakan Domba di PT Tawakal Farm Bogor
}

\author{
Evaluation Model on the Application of Good Farming Practice on PT. TF Sheep Farm Bogor \\ M. R. A. Hasan', M. Yamin' ${ }^{2}$ \& S. Rahayu ${ }^{2}$ \\ ${ }^{1}$ Ilmu Produksi dan Teknologi Peternakan, Fakultas Peternakan, IPB \\ ${ }^{2}$ Departemen Ilmu Produksi dan Teknologi Peternakan, Fakultas Peternakan, IPB \\ Jl. Agatis Kampus IPB Dramaga, Bogor \\ Email koresponden author: m_robby@rocketmail.com
}

\begin{abstract}
This research was aimed to evaluate Good Farming Practice (GFP) of sheep fattening at PT TF. The breed of sheep that are fattened in this farm are thin tailed and thick tailed. The aspects that evaluated were equipments aspect, production process, environmental conservation, and surveillance. The data were corrected by observation method and interview company leaders. Data were analyzed using descriptive analysis method with weighting based on importance aspect to GFP. The total GFP performance score were $81.90 \%$ indicated that the application of GFP PT TF was sufficiently good. It could be conclude that the point of view from the aspect of production facilities and processes, PT TF has applied good GFP with the weighted value of each aspects were $82.13 \%$ and $85.25 \%$, respectively.
\end{abstract}

Keywords : good farming practice, sheep fattening, thin tailed sheep

\section{PENDAHULUAN}

Kebutuhan produk peternakan terutama daging semakin meningkat dari tahun ke tahun sejalan dengan bertambahnya jumlah penduduk dan kesadaran masyarakat untuk memenuhi gizi yang seimbang. Produktivitas domba lokal di Indonesia turut menyumbang dalam pemenuhan kebutuhan gizi protein hewani. Selaras dengan pernyataan Harahap (2008), bahwa ternak domba lokal memiliki peran penting dalam peternakan Indonesia sebagai penghasil daging untuk memenuhi kebutuhan dalam negeri, juga berpotensi untuk memasok pasar ekspor. Ternak domba memiliki peluang pengembangan usaha yang sangat besar karena beberapa potensi pendukung antara lain aspek sosial (memelihara domba sudah menjadi budaya di masyarakat), sumber protein berupa daging yang digemari, relatif mudah dipelihara, dan bersifat prolifik (jumlah anak lebih dari 1 ekor per kelahiran) (Yamin et al. 2014).

Usaha peternakan domba berkembang pesat sejalan dengan bertambahnya populasi ternak domba yang ada di Indonesia. Jumlah ternak domba Indonesia mengalami peningkatan dalam kurun waktu 5 tahun terakhir, populasi domba pada tahun 2011 sejumlah 11.790 .700 ekor (BPS 2013) meningkat pada tahun 2016 menjadi 15.716.000 ekor (BPS 2018). Menurut Yamin et al. (2014), pertambahan jumlah tersebut sebenarnya dapat mencapai 3 kali lipat dari tahun 2011, dengan potensi ternak yang prolifik dan dapat beranak 3 kali dalam 2 tahun. Peningkatan jumlah yang kurang optimal dapat disebabkan oleh manajemen budidaya yang diterapkan belum optimal sehingga diperlukan penerapan Good Farming practice (GFP).

Menurut Kementan (2001) GFP domba/kambing merupakan pedoman dalam budidaya domba/kambing yang baik dan benar dalam beternak. Tujuan dari pedoman budidaya ternak kambing/domba yang baik tersebut yaitu meningkatkan populasi, produksi dan produktivitas ternak, meningkatkan mutu hasil ternak (daging), menunjang ketersediaan pangan asal ternak dalam negeri, menciptakan lapangan kerja, meningkatkan pendapatan dan kesejahteraan peternak, dan mendorong ekspor komoditas ternak khususnya ternak kambing/domba. Ruang lingkup pedoman budidaya ternak yang baik mencakup aspek sarana, proses produksi, pelestarian lingkungan, dan pengawasan (Kementan 2001).

PT Tawakal Farm, Caringin-Bogor merupakan salah satu perusahaan swasta nasional yang bergerak pada bidang fattening dan trading domba potong. Perusahaan ini telah berdiri sejak 1993 hingga sekarang dan telah banyak memasok domba pedaging di daerah Bogor dan sekitarnya. Penerapan GFP menjadi hal yang penting untuk diperhatikan dalam perusahaan ini untuk meningkatkan produktivitas domba pedaging yang dihasilkan. Dengan model evaluasi dari segi GFP diharapkan PT Tawakal Farm bisa menjadi peternakan dengan Standard Practice yang layak untuk penggemukan domba. Penelitian dilakukan untuk mengkaji penerapan Good Farming Practices (GFP) Penggemukan Domba di PT Tawakal Farm, Caringin Bogor. 


\section{MATERI DAN METODE}

\section{Waktu dan Tempat Penelitian}

Penelitian dilaksanakan di PT Tawakal Farm, Jl. Raya Sukabumi, Dusun Cimande Hilir No. 32, Kecamatan Caringin, Kabupaten Bogor. Penelitian ini dilakukan mulai dari bulan Februari 2018 sampai bulan Maret 2018.

\section{Bahan}

Bahan-bahan yang digunakan dalam penelitian ini adalah data primer dan data sekunder. Data primer diperoleh dari observasi dan wawancara langsung dengan pihak peternakan. Adapun data sekunder merupakan data yang diperoleh dari studi literatur, instansi terkait, dan hasil penelitian yang relevan dengan masalah penelitian.

\section{Alat}

Alat yang digunakan sebagai sarana pengumpulan data utama dalam penelitian ini adalah alat tulis, lembar wawancara, alat perekam, dan kamera.

\section{Prosedur}

Pengumpulan data primer dilakukan dengan teknik observasi dan wawancara yang berpedoman instrumen Good Farming Practice budidaya ternak kambing/domba yang baik (Kementan 2001) yang dimodifikasi untuk tujuan penggemukan.

Pembobotan aspek GFP yaitu 30\% aspek sarana dan $50 \%$ aspek proses produksi. Pembobotan tersebut didasarkan pada asumsi kepentingan produksi penggemukan ternak domba. Wawancara dilakukan kepada pihak yang kompeten atau ahli dalam perusahaan tersebut, baik pemilik dan manajer. Data sekunder diperoleh dari pihak peternakan dan beberapa literatur terkait.

\section{Peubah yang Diamati}

Peubah yang diamati adalah aspek Good Farming Practice (GFP) meliputi sarana, proses produksi, pelestarian lingkungan, dan pengawasan. Pada artikel ini akan dibahas hanya dua aspek yaitu aspek sarana dan proses produksi saja. Penjelasan tentang peubah-peubah tersebut sebagai berikut:

\section{Evaluasi Aspek Sarana}

Evaluasi aspek sarana, meliputi 9 sub aspek yaitu: lokasi, lahan, penyediaan air dan alat penerang, bangunan, alat dan mesin, bibit, pakan, obat hewan, dan tenaga kerja. Bobot sub aspek didasarkan pada tingkat kepentingan dalam produksi penggemukan.

\section{Evaluasi Aspek Proses Produksi}

Evaluasi aspek proses produksi, meliputi $6 \mathrm{sub}$ aspek yaitu: pemilihan bibit, kandang, pakan, kesehatan hewan, kesehatan masyarakat veteriner, dan penanganan hasil. Bobot sub aspek didasarkan pada tingkat kepentingan dalam produksi penggemukan.

\section{Analisis Deskriptif}

Data yang diperoleh diolah menggunakan analisis deskriptif. Analisis deskriptif digunakan untuk menggambarkan keadaan atau kondisi peternakan domba di
PT Tawakal Farm dalam penerapan Good Farming Practice (GFP) penggemukan domba. Aspek GFP yang diamati yaitu sarana, proses produksi, pelestarian lingkungan, dan pengawasan. Penilaian dilakukan berdasarkan metode skala penilaian atau rating scale (Silaen 2014) dengan rentang nilai: 1 (Penerapan GFP Buruk), 2 (Penerapan GFP Kurang Baik), 3 (Penerapan GFP Baik), dan 4 (Penerapan GFP Sangat Baik). Nilai ini disebut nilai terhitung berdasarkan nilai konversi performa peternak yang dimodifikasi (Andriyadi 2012) dan ubah menjadi nilai tertimbang berdasarkan Puspitasari 2008 yang dimodifikasi dengan rumus berikut:

$$
c=\frac{b}{4} \times a
$$

Keterangan :

$\mathrm{a}=$ Bobot sub aspek (\%);

$\mathrm{b}=$ Nilai terhitung dengan selang 1-4; dan

$\mathrm{c}=$ Nilai tertimbang $(\%)$.

Setelah itu dilanjutkan dengan perhitungan nilai performa GFP metode Puspitasari 2008 dengan modifikasi. Perhitungannya adalah bobot masing-masing aspek dikalikan nilai terhitung, sehingga akan didapatkan nilai tertimbang lalu dijumlahkan. Rumus yang digunakan untuk mendapatkan nilai performa GFP yaitu:

$$
\mathrm{Y}=(\mathrm{A}+\mathrm{B}+\mathrm{C}+\mathrm{D})
$$

Keterangan :

$\mathrm{Y}=$ Nilai performa GFP peternakan;

$\mathrm{A}=$ Nilai performa GFP aspek sarana;

$\mathrm{B}=$ Nilai performa GFP aspek proses produksi;

$\mathrm{C}=$ Nilai performa GFP aspek pelestarian lingkungan; dan $\mathrm{D}=$ Nilai performa GFP aspek pengawasan.

Nilai A, B, C, dan D diperoleh dari perhitungan sebagai berikut :

$A=$ Total nilai tertimbang aspek sarana $\times$ bobot $(30 \%)$

$\mathrm{B}=$ Total nilai tertimbang aspek proses produksi $\times$ bobot $(50 \%)$

$\mathrm{C}=$ Total nilai tertimbang aspek pelestarian lingkungan $\times$ bobot $(10 \%)$

$\mathrm{D}=$ Total nilai tertimbang aspek pengawasan $\times$ bobot $(10 \%)$

Terdapat perbedaan bobot pada masing-masing aspek. Sarana dan proses produksi memiliki bobot yang lebih besar dibandingkan aspek pelestarian lingkungan dan pengawasan. Pemberian bobot tersebut didasarkan pada asumsi dan tingkat kepentingan komponen sub aspek dalam apek sarana dan proses produksi dalam berjalannya produksi penggemukan ternak domba.

Pembobotan tersebut didasarkan pada pernyataan Yamin et al. (2014) yang menyatakan beberapa faktor penting yang perlu diperhatikan dalam usaha penggemukan yaitu umur bakalan domba, lingkungan yang optimal (pakan dan kandang), penggunaan bangsa domba cepat tumbuh, dan pakan yang menghasilkan karkas dan daging yang baik. Faktor-faktor tersebut termasuk dalam aspek sarana 
dan proses produksi sehingga bobot dari 2 aspek tersebut lebih besar dari yang lainnya. Selanjutnya dilakukan proses verifikasi dan penyamaan persepsi hasil penelitian kepada pihak peternakan untuk mendapat hasil yang bisa diterima.

Klasifikasi performa GFP peternakan secara umum dilihat dari nilai yang dihasilkan Puspitasari 2008. Berdasarkan nilai yang diperoleh, maka performa peternakan dikategorikan sebagai berikut:

1) Jika nilai GFP peternakan $<55 \%$, maka kategori GFP di peternakan tersebut KURANG;

2) Jika nilai GFP peternakan $\geq 55-75 \%$, maka kategori GFP di peternakan tersebut CUKUP;

3) Jika nilai GFP peternakan $\geq 75-90 \%$, maka kategori GFP di peternakan tersebut BAIK; dan

4) Jika nilai GFP peternakan $>90 \%$, maka kategori GFP di peternakan tersebut SANGAT BAIK

\section{HASIL DAN PEMBAHASAN}

\section{Keadaan Umum Peternakan}

Peternakan domba PT. Tawakal Farm berlokasi di Jl. Raya Sukabumi, Desa Cimande Hilir No. 32, Kecamatan Caringin, Kabupaten Bogor. Daerah peternakan berbatasan langsung dengan Dusun Lemah Duhur di sebelah Barat, Desa Ciderum di sebelah Timur, desa Caringin di Sebelah Utara dan Selatan. Keadaan topografi datar dengan ketinggian berkisar antara 400-700 m dpl. Temperatur lingkungan memiliki kisaran suhu antara $21-30{ }^{\circ} \mathrm{C}$ dengan kelembaban udara 70\% - 80\% dan curah hujan 3.000-3.400 mm tahun ${ }^{-1}$.

Lokasi peternakan berjarak sekitar $20 \mathrm{~m}$ dari pemukiman warga, cukup dekat namun tidak mengganggu masyarakat sekitar. Lokasi peternakan cukup strategis karena peternakan hanya berjarak $300 \mathrm{~m}$ dari jalan raya. Keadaan ini mendukung kelancaran transportasi dan distribusi.

Luas area peternakan mencapai 2,1 ha dilengkapi dengan berbagai sarana untuk mendukung proses produksi. Sarana tersebut antara lain kantor administrasi, mess karyawan, gudang pakan, enam kandang pemeliharaan domba yaitu kandang A, B, C, D, E, dan F, dan mobil sebagai sarana transportasi.

\section{Perkembangan Usaha PT Tawakal Farm}

Peternakan ini resmi didirikan pada tahun 1993 oleh Bapak Bunjamin. Usaha mulai difokuskan pada peternakan domba sejak tahun 1990. Pendirian peternakan ini dilatarbelakangi oleh kegemaran pemilik terhadap ternak domba. Jumlah ternak yang dipelihara pada awal pendirian hanya sebanyak 6 ekor yang dikandangkan di belakang rumah. Jumlah ternak yang dipelihara meningkat pada 1991 mencapai 40 ekor, kemudian meningkat kembali pada tahun 1992 sebanyak 70 ekor. Kandang B dibangun pada 1993 dengan kapasitas domba sebanyak 112 ekor, kemudian disusul pembangunan kandang A pada 1995 dengan daya tampung sebanyak 242 ekor.

Permintaan domba semakin meningkat terutama pada hari raya Idul Adha, maka pemilik menambah jumlah kandang pada tahun 1996 dan kandang D dan E pada tahun 1997 dengan daya tampung masing-masing 400 ekor dan meningkat terus sampai saat ini. Pada tahun 2017 dilakukan renovasi kandang dan penambahan kandang darurat untuk keperluan penampungan domba bakalan bunting yang beranak. Jumlah domba yang dipelihara meningkat tiap tahunnya dan saat ini domba yang dipelihara mencapai 1.700 ekor.

\section{Evaluasi Sarana}

Sarana merupakan aspek pertama yang disebut dalam penerapan Good Farming Practice. PT Tawakal Farm mendapat hasil nilai tertimbang sebesar $82,88 \%$ yang menunjukkan peternakan telah melakukan GFP aspek sarana dengan baik. Nilai tersebut didapat dari penilaian sub aspek dalam aspek sarana. Hasil nilai tertimbang GFP aspek sarana dan sub aspek yang dievaluasi secara keseluruhan terdapat pada Tabel 1.

\section{Lokasi}

Lokasi peternakan menurut Rencana Tata Ruang dan Wilayah (RTRW) termasuk kurang baik (nilai terhitung 2) karena lokasi peternakan dekat dengan pemukiman penduduk, menurut Kepmentan 2001 minimal jarak bangunan peternakan dengan bukan peternakan adalah 25 $\mathrm{m}$ sedangkan jarak peternakan dengan pemukiman hanya sekitar $20 \mathrm{~m}$. Lokasi peternakan termasuk wilayah PD 2 atau kawasan permukiman perdesaan di dalam kawasan lindung di luar kawasan hutan Kabupaten Bogor (Gambar 1).

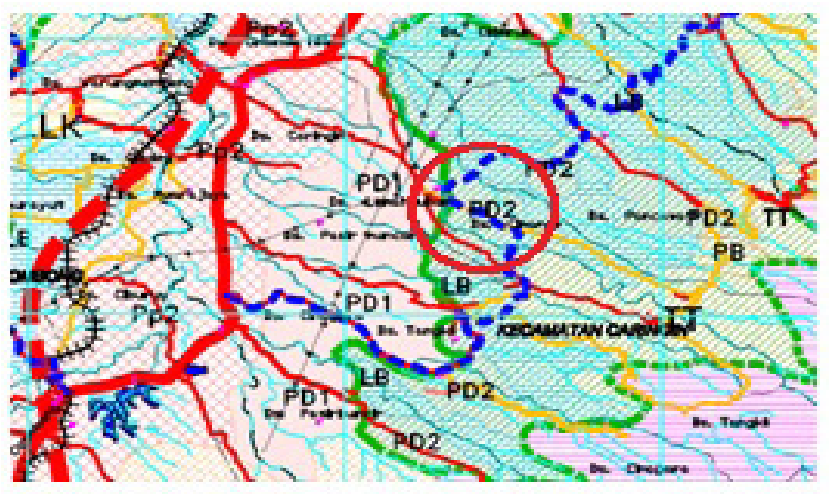

Gambar 1. Lokasi Peternakan dalam peta RTRW Kabupaten Bogor

Lokasi tersebut meskipun kurang baik namun sesuai untuk peternakan karena diarahkan untuk aktivitas masyarakat desa maupun terhadap potensi lingkungan sekitar seperti pertanian, peternakan, kehutanan, pariwisata atau agrowisata namunbukan spesifik daerah peternakan (Perda 2008).

Topografi lahan peternakan termasuk baik (nilai terhitung 3) karena cukup datar dengan ketinggian berkisar antara 400-700 m dpl. Kotoran tidak mencemari wilayah sekitar karena ditampung di bawah kandang selama periode tertentu dan tidak dibuang ke saluran pembuangan yang terhubung ke sungai.

\section{Lahan}

Status lahan merupakan lahan pribadi yang digunakan untuk usaha peternakan. Lahan dapat digunakan untuk usaha peternakan karena termasuk daerah PD 2 dalam RTRW wilayah Kabupaten Bogor (nilai terhitung 4). 
Hasan et al.

Jurnal Ilmu Produksi dan Teknologi Hasil Peternakan 6 (2): 60-66

Tabel 1. Evaluasi GFP aspek sarana

\begin{tabular}{|c|c|c|c|c|c|}
\hline No & Sub Aspek & Kondisi Seharusnya & $\begin{array}{l}\text { Bobot } \\
(\%)\end{array}$ & $\begin{array}{c}\text { Nilai } \\
\text { terhitung } \\
(1-4)\end{array}$ & $\begin{array}{c}\text { Nilai } \\
\text { tertimbang } \\
(\%)\end{array}$ \\
\hline \multirow[t]{2}{*}{1} & \multirow[t]{2}{*}{ Lokasi } & - Sesuai RTRW dan berjarak minimal $25 \mathrm{~m}$ dari pemukiman & 3,0 & 2 & 1,50 \\
\hline & & - Topografi mencegah dari pencemaran & 2,0 & 3 & 1,50 \\
\hline 2 & Lahan & - Status lahan jelas sesuai peraturan perundang-undangan & 5,0 & 4 & 5,00 \\
\hline \multirow[t]{2}{*}{3} & \multirow{2}{*}{$\begin{array}{l}\text { Penyediaan } \\
\text { air dan alat } \\
\text { penerang }\end{array}$} & - Memenuhi baku mutu air, dapat diminum, dan tersedia sepanjang tahun & 2,5 & 4 & 2,50 \\
\hline & & - Menyediakan alat penerang dan listrik & 2,5 & 4 & 2,50 \\
\hline \multirow[t]{11}{*}{4} & \multirow[t]{11}{*}{ Bangunan } & - Terdapat bangunan peternakan, yaitu: & 5,0 & 3 & 3,75 \\
\hline & & Kandang penggemukan bakalan; & & & \\
\hline & & Kandang isolasi ternak sakit; & & & \\
\hline & & 3) Gudang pakan dan peralatan; & & & \\
\hline & & Barak pekerja; dan & & & \\
\hline & & Penampungan dan pengolahan limbah. & & & \\
\hline & & - Konstruksi bangunan & 5,0 & 4 & 5,00 \\
\hline & & Memenuhi daya tampung dan menjamin masuknya udara segar & & & \\
\hline & & 2) Memiliki saluran pembuangan & & & \\
\hline & & $\begin{array}{l}\text { 3) Bahan ekonomis, mudah untuk pemeliharaan, pembersihan dan } \\
\text { desinfeksi kandang }\end{array}$ & & & \\
\hline & & 4) menjamin ternak dari kecelakaan dan kerusakan fisik & & & \\
\hline \multirow[t]{3}{*}{5} & \multirow{3}{*}{$\begin{array}{l}\text { Alat dan } \\
\text { mesin } \\
\text { peternakan }\end{array}$} & $\begin{array}{l}\text { - Terdapat tempat pakan, alat sanitasi, pengendalian penyakit, dan peralatan } \\
\text { pendukung lain }\end{array}$ & 2,0 & 4 & 2,00 \\
\hline & & - Mudah digunakan dan aman untuk kesehatan & 1,5 & 3 & 1,13 \\
\hline & & - Peralatan ternak sakit tidak boleh dipakai dikandang lain & 1,5 & 2 & 0,75 \\
\hline \multirow[t]{3}{*}{6} & \multirow[t]{3}{*}{ Bakalan } & - Memenuhi kriteria persyaratan, jenis dan mutu bakalan yang berlaku & 8,0 & 3 & 6,00 \\
\hline & & $\begin{array}{l}\text { - Berasal dari daerah sumber bakalan atau dari perusahaan yang memiliki izin } \\
\text { usaha peternakan }\end{array}$ & 6,0 & 2 & 3,00 \\
\hline & & $\begin{array}{l}\text { - Tata cara pemasukan bakalan ternak wajib mengikuti peraturan perundang- } \\
\text { undangan yang berlaku }\end{array}$ & 6,0 & 4 & 6,00 \\
\hline \multirow[t]{4}{*}{7} & \multirow{4}{*}{$\begin{array}{l}\text { Kecukupan } \\
\text { Pakan }\end{array}$} & - Menjamin jumlah dan mutunya sesuai standar/kebutuhan yang berlaku & 9,0 & 4 & 9,00 \\
\hline & & - Menyediakan pakan hijauan yang cukup dan kontinu & 8,0 & 4 & 8,00 \\
\hline & & - Pakan hijauan dapat dilakukan kerjasama dengan masyarakat tani setempat & 7,0 & 3 & 5,25 \\
\hline & & $\begin{array}{l}\text { - Sediaan premix dan sediaan obat alami telah mendapatkan nomor } \\
\text { pendaftaran }\end{array}$ & 6,0 & 4 & 6,00 \\
\hline \multirow[t]{2}{*}{8} & \multirow[t]{2}{*}{ Obat hewan } & - Obat-obatan sudah terdaftar & 2,5 & 4 & 2,50 \\
\hline & & - Penggunaan sesuai ketentuan yang berlaku & 2,5 & 4 & 2,50 \\
\hline \multirow[t]{3}{*}{9} & \multirow[t]{3}{*}{ Tenaga Kerja } & - Pekerja hendaknya berbadan sehat & 3,0 & 4 & 3,00 \\
\hline & & - Mendapat pelatihan teknis produksi dll & 4,0 & 3 & 3,00 \\
\hline & & - Sesuai ketentuan peraturan perundang-undangan dibidang ketenaga kerjaan & 3,0 & 3 & 2,25 \\
\hline TOT & & & 100,0 & & 82,13 \\
\hline
\end{tabular}

\section{Penyediaan Air dan Alat Penerang}

Air yang digunakan bersumber dari sumur. Air tersebut sudah memenuhi baku mutu air yang sehat karena dapat diminum oleh manusia dan ternak dan tersedia sepanjang tahun (nilai terhitung 4). Alat penerang seperti lampu sudah ada dan cukup sesuai kebutuhan penerangan (nilai terhitung 4).

\section{Bangunan}

Bangunan peternakan sudah meliputi 4 kandang penggemukan bakalan, 1 kandang bunting, kantor, gudang pakan dan peralatan, barak pekerja/mess, dan penampungan limbah. Menurut GFP sarana bangunan peternakan sudah baik namun kurang ideal karena belum terdapat kandang isolasi ternak sakit dan pengolahan limbah (nilai terhitung $3)$. 
Konstruksi kandang juga sudah baik (nilai terhitung 4) dengan ventilasi besar untuk sirkulasi udara, terbuat dari bahan ekonomis yang didominasi oleh kayu dan bambu serta beton untuk pondasi kandang panggung. Kandang cukup mudah untuk dibersihkan karena celah alas kandang cukup untuk dilewati kotoran dan tidak menyebabkan ternak terperosok.

\section{Alat dan Mesin Peternakan}

Alat dan mesin peternakan yang ada sudah memadai (nilai terhitung 4). Alat pakan tersedia untuk tiap kandang, air minum disediakan ad libitum, dan alat kebersihan tersedia pada setiap kandang. Peralatan mencukur wool tersedia baik mesin cukur ataupun gunting. Tersedia 2 mobil pick-up untuk sarana transportasi untuk mengangkut bakalan atau mengantar domba yang dipanen, dan terdapat juga peralatan lainnya seperti feedmill.

Peralatan tersebut relatif mudah penggunaanya dan pembersihannya (nilai terhitung 3), namun pemakaian alat masih tercampur antara ternak sakit dan ternak sehat sehingga kurang baik untuk proses produksi (nilai terhitung 2).

\section{Bakalan}

Daerah sumber bakalan meliputi Temanggung, Garut, Jampang, Sukabumi, dan Kendal. Mayoritas sumber bakalan belum memiliki izin ternak karena masih dalam bentuk peternakan tradisional dan pihak belantik, kecuali Batavia Farm yang berasal dari Kendal yang sudah memiliki izin usaha (nilai terhitung 2). Bakalan yang digunakan umumnya domba ekor tipis (DET) betina untuk pemotongan harian, DET jantan tanduk dan dugul (tanpa tanduk) untuk dijual mendekati hari raya Idul Adha, dan domba ekor gemuk (DEG) betina yang juga untuk pemotongan harian.

Penggunaan bakalan sudah memperhatikan persyaratan jenis dan mutu bakalan yang berlaku mengacu pada Purbowati (2014) yang menyatakan bahwa domba yang banyak digemukan di Indonesia yaitu DEG dan DET (nilai terhitung 4). Pemasukan bakalan sudah baik (nilai terhitung 4) karena ternak dari dalam negeri tidak diharuskan untuk mengurus administrasi khusus, mengacu pada Permentan (2008) yang menyatakan ternak dari luar Negara Republik Indonesia harus memperhatikan persyaratan pemasukan ternak potong dan tata cara pemasukan ternak.

\section{Kecukupan Pakan}

Pakan yang disediakan terbagi menjadi hijauan rumput lapang, ampas tahu, dan konsentrat. Jumlah yang diberikan yaitu $470 \mathrm{~g}$ konsentrat, 1,5 $\mathrm{kg}$ ampas tahu, dan 380 g rumput per ekor per hari. Jika dikonversi dalam BK maka akan menjadi 415,48 g konsentrat, $240 \mathrm{~g}$ ampas tahu, dan $80 \mathrm{~g}$ rumput. Total bobot pakan dalam BK yaitu 735,48 g, atau 4,9\% dari bobot badan ternak dengan rata-rata bobot badan $15 \mathrm{~kg}$.

Kebutuhan BK sudah cukup (nilai terhitung 4) selaras dengan Tomazewka et al. (1993) yang menyatakan bahwa kebutuhan bahan kering per ekor per hari untuk domba Indonesia dengan bobot tubuh 10-20 kg adalah $3,1 \%-4,7 \%$ dari bobot tubuh untuk pertambahan bobot tubuh sebesar 0-100 $\mathrm{g} \mathrm{ekor}^{-1}$ hari $^{-1}$. Pakan hijauan tersedia secara kontinu (nilai terhitung 4) dari kebun sendiri maupun hijauan rumput dari masyarakat setempat (nilai terhitung 3). Premix yang digunakan berasal dari CV. Fenanza Putra dan sudah mendapat nomor pendaftaran dari Kementan (nilai terhitung 4).

\section{Obat Hewan}

Penggunaan obat-obatan sudah baik (nilai terhitung 4) karena obat hewan yang digunakan sudah memiliki nomor pendaftaran dari Kementan. Penggunaanya juga sesuai dengan dosis yang dianjurkan (nilai terhitung 4), dengan demikian penggunaan obat hewan pada peternakan ini sudah baik.

\section{Tenaga Kerja}

Total pekerja yang ada di peternakan berjumlah 18 orang, terbagi menjadi 6 orang kepala kandang, 6 orang anak kandang, dan selebihnya keamanan dan transportasi. Pekerja berbadan sehat dan dapat bekerja dengan baik sesuai dengan syarat GFP sehingga mendapat nilai terhitung 4. Pelatihan tidak diberikan secara langsung namun didapat dengan pengalaman bekerja secara terus menerus dan arahan dari pemilik dan manager (nilai terhitung 3).

Ketentuan mengenai tenaga kerja yang dijalankan sudah tergolong baik (nilai terhitung 3), ketenaga kerjaan mengacu pada Undang-Undang No 13 Tahun 2003 tentang ketenaga kerjaan perihal kelayakan gaji yang diberikan sesuai UMR.

\section{Evaluasi Proses Produksi}

Proses produksi merupakan aspek kedua yang disebut dalam penerapan Good Farming Practice. Penilaian terhadap PT Tawakal Farm mendapat hasil nilai tertimbang GFP aspek proses produksi sebesar 85,25\% yang menunjukkan peternakan telah melakukan GFP aspek proses produksi dengan baik. Hasil nilai performa GFP aspek proses produksi secara keseluruhan terdapat pada Tabel 2.

\section{Pemilihan Bakalan}

Pemilihan bakalan mendapat nilai terhitung 4, sangat baik karena memperhatikan kondisi fisik, terutama dari kesehatan dan cacat fisik. Jika terdapat bakalan yang memiliki cacat fisik seperti kebutaan, tanduk patah, pincang, lumpuh, kaki dan kuku abnormal, serta cacat lainnya maka akan dikembalikan. Secara khusus bakalan yang dipilih memenuhi syarat (nilai terhitung 3) tetapi tidak memperhatikan umur bakalan.

Peternakan lebih memilih bobot badan dan tingkat pertambahan bobot badan. Bobot badan bakalan berkisar antara $12-20 \mathrm{~kg}$. Rataan pertambahan bobot badan harian domba mencapai $118 \mathrm{~g}$ ekor $^{-1}$ hari $^{-1}$. Hasil tersebut lebih baik dari Yamin et al. (2009) yang melaporkan bahwa pertambahan bobot badan harian domba lokal dapat mencapai 98 g ekor $^{-1}$ hari $^{-1}$.

\section{Kandang}

Kandang panggung memiliki konstruksi yang sangat baik (nilai terhitung 4). Kriteria tersebut karena kandang yang kokoh, mudah untuk dibersihkan, siklus udara yang bebas dan dilengkapi tempat pakan dan minum ternak, 
Tabel 2. Evaluasi GFP aspek proses produksi

\begin{tabular}{|c|c|c|c|c|c|}
\hline \multirow[t]{2}{*}{ No } & \multirow[t]{2}{*}{ Sub Aspek } & \multirow[t]{2}{*}{ Kondisi seharusnya } & \multirow{2}{*}{$\begin{array}{l}\text { Bobot } \\
(\%) \\
\end{array}$} & \multirow{2}{*}{$\begin{array}{c}\text { Nilai } \\
\text { terhitung } \\
(1-4)\end{array}$} & \multirow{2}{*}{$\begin{array}{c}\text { Nilai } \\
\text { tertimbang } \\
(\%)\end{array}$} \\
\hline & & & & & \\
\hline \multirow[t]{5}{*}{1} & \multirow{5}{*}{$\begin{array}{l}\text { Pemilihan } \\
\text { bakalan }\end{array}$} & - Secara umum memenuhi kriteria sehat dan bebas dari segala cacat fisik & 10 & 4 & 10 \\
\hline & & - Secara khusus & 10 & 3 & 7,5 \\
\hline & & Umur $8-12$ bulan & & & \\
\hline & & Berat badan $15-25 \mathrm{~kg}$ & & & \\
\hline & & 3) Pertambahan bobot badan $100 \mathrm{~g}$ ekor-1 hari-1 & & & \\
\hline \multirow[t]{3}{*}{2} & \multirow[t]{3}{*}{ Kandang } & $\begin{array}{l}\text { - Kokoh, baik untuk kesehatan, mudah dibersihkan, drainase baik, siklus udara } \\
\text { bebas dan dilengkapi tempat pakan dan minum }\end{array}$ & 7 & 4 & 7 \\
\hline & & - Sistem kandang koloni dengan luasan $1 \mathrm{~m} 2$ ekor-1 untuk dewasa & 7 & 3 & 5,25 \\
\hline & & - Jarak dengan bangunan bukan kandang minimal $25 \mathrm{~m}$ & 6 & 2 & 3 \\
\hline \multirow[t]{4}{*}{3} & \multirow[t]{4}{*}{ Pakan } & - Terdiri dari pakan dasar berupa hijauan dan konsentrat & 10 & 4 & 10 \\
\hline & & - Terjamin jumlah dan mutunya sesuai kebutuhan minimum & 10 & 4 & 10 \\
\hline & & $\begin{array}{l}\text { - Kebutuhan zat-zat seperti protein, energi, serat kasar terpenuhi. Vitamin dan } \\
\text { mineral harus diberikan }\end{array}$ & 10 & 4 & 7,5 \\
\hline & & - $\quad$ Memiliki kandungan PK 10\%-15\%, TDN 55-60 & 10 & 4 & 10 \\
\hline 4 & $\begin{array}{l}\text { Kesehatan } \\
\text { Hewan }\end{array}$ & $\begin{array}{l}\text { - Melakukan upaya pengendalian, pemberantasan dan pengobatan penyakit } \\
\text { hewan menular sesuai dengan peraturan yang berlaku }\end{array}$ & 5 & 4 & 5 \\
\hline \multirow[t]{8}{*}{5} & \multirow{8}{*}{$\begin{array}{l}\text { Kesehatan } \\
\text { Masyarakat } \\
\text { Veteriner }\end{array}$} & - Melakukan perhatian khusus terhadap hal berikut: & 5 & 2 & 2,5 \\
\hline & & a) Lokasi tidak mudah dimasuki oleh binatang liar & & & \\
\hline & & b) Melakukan desinfeksi peralatan dan kandang & & & \\
\hline & & Melakukan penyemprotan insektisida & & & \\
\hline & & d) Melaksanakan sanitasi dan menjaga kebersihan peternakan & & & \\
\hline & & e) Menerapkan biosekuriti lalulintas orang dan kendaraan & & & \\
\hline & & $\begin{array}{l}\text { f) Bangkai ternak dilarang dibawa keluar kompleks peternakan, harus di } \\
\text { musnahkan }\end{array}$ & & & \\
\hline & & g) Melakukan vaksinasi dan pengobatan hewan sakit & & & \\
\hline 6 & $\begin{array}{l}\text { Penanganan } \\
\text { Hasil }\end{array}$ & $\begin{array}{l}\text { - Ternak diangkut dengan alat transportasi khusus, penggunaan antibiotik mem } \\
\text { perhatikan waktu henti obat }\end{array}$ & 10 & 3 & 7,5 \\
\hline $\mathrm{TO}^{-}$ & & & 100 & & 85,25 \\
\hline
\end{tabular}

dan drainase kandang. Tipe kandang panggung membuat drainase tidak terhubung dengan saluran pembuangan dan kotoran terakumulasi di bawah kandang yang dibersihkan secara berkala.

Sistem kandang koloni untuk penggemukan domba potong harian memiliki luasan $0,44 \mathrm{~m}^{2}$ ekor $^{-1}$ untuk kandang F, 0,79 $\mathrm{m}^{2}$ ekor $^{-1}$ untuk kandang $\mathrm{D}$, dan $0,45 \mathrm{~m}^{2}$ ekor ${ }^{-1}$ untuk kandang A. Luasan tersebut baik (nilai terhitung 3) karena ternak masih bisa bergerak bebas walau luasannya tidak mencapai $1 \mathrm{~m}^{2}$ ekor ${ }^{-1}$. Posisi kandang dekat dengan barak pekerja, kantor, dan mess yang hanya berjarak $3 \mathrm{~m}$ sehingga tidak sesuai dengan acuan (nilai terhitung 2) yang menyatakan minimal jarak kandang dengan bangunan bukan kandang sejauh $25 \mathrm{~m}$. Namun, jarak yang dekat memudahkan untuk pemantauan kondisi kandang selama pemeliharaan.

\section{Pakan}

Pakan yang diberikan sudah sangat baik karena terdiri dari pakan hijauan, ampas tahu dan konsentrat (nilai terhitung 4). Jumlah dan mutu pakan sudah sesuai kebutuhan minimum (nilai terhitung 4). Kandungan nutrisi total ransum yang diberikan memiliki PK 17\%, TDN 68, dan SK 17\%. Kebutuhan PK sudah mencukupi (nilai terhitung 4) sesuai dengan Umberger (2009) yang menyatakan kebutuhan PK untuk domba dengan bobot 13,6-31,7 kg yaitu 15\%, sedangkan Haryanto (1993) menyatakan kebutuhan PK ternak domba sebesar 14\%-15\%. Kandungan PK tersebut juga sudah melebihi yang disarankan oleh Yamin et al. (2014) yaitu sebanyak $12 \%$.

TDN ransum domba sudah mencukupi bahkan melebihi kebutuhan selaras dengan Ranjhan (1981) yang menyatakan kebutuhan TDN ransum domba yang digemukkan yaitu 55\%-60\%, selaras juga dengan Yamin et al. (2014) sebanyak 55\%. TDN belum mencukupi jika mengacu pada Umberger (2009) yang menyatakan kebutuhan TDN yaitu 70\%-75\% untuk bobot badan 22,5$33,75 \mathrm{~kg}$. Premix yang merupakan sumber vitamin dan mineral dirahasiakan jumlahnya tapi sudah diberikan dalam pakan konsentrat (nilai terhitung 3).

\section{Kesehatan Hewan}

Upaya pengendalian, pemberantasan, dan pengobatan penyakit hewan menular sudah dilaksanakan dengan sangat 
baik (nilai terhitung 4). Hal tersebut karena penanganan intensif ternak sakit walau tidak memiliki kandang isolasi. Penyakit menular yang umum ditemukan di peternakan ini yaitu scabies, kutu, penyakit cacing (haemonchiasis dan fasciolisis), orf (Contangious Pustular Dermatitis), dan sakit mata.

Obat yang biasa digunakan untuk penyakit cacing yaitu Kalbazen ${ }^{\circledR}-\mathrm{C}$, untuk scabies dan kutu digunakan injeksi Wormectin ${ }^{\circledR}$. Penanganan Orf dengan Limoxin-25 spray dari interchemie. Penanganan sakit mata dengan pemberian Tylovet-meyer atau Pyrikol-Drops.

\section{Kesehatan Masyarakat Veteriner}

Pemantauan sub aspek ini merupakan upaya untuk pengamanan kesehatan hewan dan kesehatan masyarakat veteriner. Sub aspek ini mendapat nilai terhitung 2, kurang baik karena terdapat beberapa hal yang belum diterapkan. Beberapa hal tersebut seperti pengamanan lalu lintas manusia, kendaraan, dan hewan dari luar ke dalam kompleks peternakan.

Pembersihan kandang rutin dilakukan namun disinfeksi kandang dan peralatan jarang dilakukan. Sistem penghapus hama atau biosecurity belum diterapkan bagi orang atau kendaraan yang keluar masuk kompleks peternakan. Bangkai ternak yang mati tidak dikubur atau dimusnahkan, ada pihak dari luar yang dapat mengambil bangkai tersebut. Hal yang sudah diterapkan untuk menjaga kesehatan masyarakat veteriner yaitu telah dilaksanakannnya tindakan pengobatan atau pencegahan penyakit (orf, cacingan, kembung, dll), menjaga kebersihan kompleks peternakan, dan melakukan penyemprotan insektisida sesekali jika diperlukan.

\section{Penanganan Hasil}

Ternak yang dipotong pada saat panen kemudian diangkut dengan mobil pick-up. Modifikasi dilakukan terhadap bak mobil tersebut hingga dapat mengangkut hingga 40 ekor domba. Biasanya ternak yang diangkut untuk disembelih berjumlah 7-10 ekor tiap harinya, penyembelihan dilakukan di TPH yang berada di daerah Sentul. Karkas kemudian didistribusikan ke konsumen. Penanganan ternak sudah baik (nilai terhitung 3), kendaraan yang digunakan sudah dimodifikasi untuk meminimalkan cidera, namun masih ada kemungkinan cidera dan tidak nyaman selama pengangkutan.

\section{KESIMPULAN}

Model evaluasi Good Farming Practice penggemukan domba di PT Tawakal Farm ditinjau dari aspek sarana dan proses produksi sudah menerapkan GFP dengan baik dengan nilai tertimbang masing-masing $82,88 \%$ dan $85,25 \%$. Nilai performa GFP di PT Tawakal Farm termasuk kategori baik dan dapat dijadikan standard practice bagi perternakan domba di Indonesia.

\section{DAFTAR PUSTAKA}

Andriyadi, A. 2012. Kajian penerapan good dairy farming practices pada peternakan sapi perah rakyat di Kelurahan Kebon Pedes Kecamatan Tanah Sareal Bogor. Skripsi. Bogor (ID): Institut Pertanian Bogor.

BPS (Badan Pusat Statistik). 2013. Statistik Indonesia 2013. Jakarta (ID): Badan Pusat Statistik

BPS (Badan Pusat Statistik). 2018. Statistik Indonesia 2018. Jakarta (ID): Badan Pusat Statistik

Harahap A.S. 2008. Pengaruh umur terhadap performa reproduksi induk domba lokal yang digembalakan di UP3 Jonggol. Skripsi. Bogor (ID): Institut Pertanian Bogor.

Haryanto, B \& A. Djajanegara. 1993. Pemenuhan Kebutuhan Zat-zat Makanan Ternak Ruminansia Kecil. (dalam) Tomaszewska WM, Mastika IM, Djajanegara A, Gradier S, Wiradaya TR (editor). Surakarta(ID): Sebelas Maret University Pr.

Kementrian Pertanian. 2001. Keputusan Menteri Pertanian RI: Pedoman Budidaya Ternak Kambing/Domba yang Baik. Jakarta (ID): Kementrian Pertanian

Kementrian Pertanian. 2008. Peraturan Menteri Pertanian: No. 07/permentan/ot.140/1/2008 tentang Syarat dan Tata Cara Pemasukan dan Pengeluaran Benih, Bibit Ternak, dan Ternak Potong. Jakarta (ID): Kementrian Pertanian

Office International des Epizooties. 2006. Guide to good farming practices or animal production food safety. Animal Production Food Safety Working Group. Paris (FR): World Organization for Animal Health (OIE)

Peraturan Daerah. 2008. Peraturan Daerah Kabupaten Bogor Nomor 19 Tahun 2008 tentang Rencana tata Ruang Wilayah Kabupaten Bogor Tahun 2005-2025. Bogor (ID): Bupati Bogor

Purbowati, E. Usaha Penggemukan Domba. Penebar Swadaya, Jakarta.

Puspitasari, M. A. 2008. Kajian penerapan good farming practices dan good hygienic practices pada KSU Jaya Abadi Kabupaten Blitar Jawa Timur. Skripsi. Bogor (ID): Institut Pertanian Bogor

Ranjhan, S. K. 1981. Animal Nutrition in Topics, Edisi ke2. New Delhi (IN): vikas Publishing House PVT LTD

Silaen, S. 2014. Metodologi Penelitian Sosial untuk Penulisan Skripsi dan Tesis. Bogor (ID): IN Media

Tomaszewska, M. W., I. M. Mastika, A. Djajanegara, S. Gardiner, T. R. Wiradaya (Eds). 1993. Produksi Kambing dan Domba di Indonesia. Sebelas Maret University Pr, Surakarta.

Umberger, S. H. 2009. Whole-grain Diet for Finishing Lamb. Viginia Cooperative Extension, Virginia.

Yamin, M., C. Sumantri, S. Rahayu, M. Duldjaman , M. Baihaqi, E.L. Aditia \& A.M.I. Dogong. 2009. Increasing local sheep growth performance through rapid selection at fattening farm. International Seminar on Animal Industry. Bogor (ID): Bogor Agricultural University

Yamin, M., S. Rahayu, M. Baihaqi \& D. Maman. 2014. Teknologi Produksi Ternak Domba dan Kambing. IPB Pr, Bogor. 